\title{
Bioprocessing of Waste Sago Pulp Fiber Based on Chloride Solution for Cellulose Isolation
}

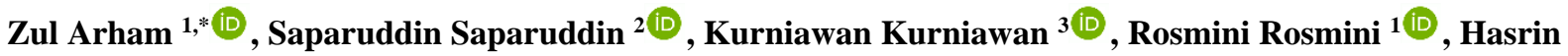 \\ Lamote $^{1 \text { (iD }}$ \\ 1 Department of Mathematics and Natural Sciences, Faculty of Tarbiyah, Institut Agama Islam Negeri (IAIN) Kendari, \\ 93116, Southeast Sulawesi, Indonesia \\ 2 Department of Biology Education, Faculty of Teacher Training and Education, Universitas Sembilanbelas November \\ Kolaka, 93517, Southeast Sulawesi, Indonesia \\ 3 Department of Textile Chemistry, Politeknik STTT Bandung, 40272, West Java, Indonesia \\ * Correspondence: arhamzul88@yahoo.com (Z.A.);
}

Scopus Author ID 57195056274

Received: 8.03.2021; Revised: 8.04.2021; Accepted: 11.04.2021; Published: 20.04.2021

\begin{abstract}
The utilization of chloride solution in the bioprocessing of sago pulp fiber waste (SPFW) aims to obtain high purity cellulose before its use in making bioethanol. Before the bioprocessing, SPFW with a powder size of $149 \mu \mathrm{m}$ was immersed in $15 \%$ (v/v) $\mathrm{NH}_{4} \mathrm{OH}$ and $5 \%$ (v/v) $\mathrm{H}_{2} \mathrm{O}_{2}$ solution. Bioprocessing parameters reported in this study included bioprocessing time, chloride solution concentration, and bioprocessing temperature. Based on the optimization results, the SPFW bioprocessing for 5 hours using $4 \%$ hydrochloric acid and a temperature of $95^{\circ} \mathrm{C}$ was the optimum condition with the acquisition of cellulose content of $67 \%$. SPFW cellulose was confirmed by the presence of specific IR absorption peaks at wave numbers $1429.4 \mathrm{~cm}^{-1}, 1322.4 \mathrm{~cm}^{-1}, 1157.3 \mathrm{~cm}^{-1}, 1110$ $\mathrm{cm}^{-1,}$ and $897 \mathrm{~cm}^{-1}$. Scanning Electron Microscopy (SEM) analysis shows that bioprocessing using chloride solutions produces a porous, rough, and fibrous cellulose surface. Also, the fiber length is irregular with the irregular location. Based on XRD analysis, SPFW bioprocessing produced singlephase cellulose with a crystal size of $15 \mathrm{~nm}$. Physically, the bioprocessing causes the discoloration of the sago pulp fiber to turn dark brown.
\end{abstract}

Keywords: cellulose; chloride solution; optimization process; SPFW.

(C) 2021 by the authors. This article is an open-access article distributed under the terms and conditions of the Creative Commons Attribution (CC BY) license (https://creativecommons.org/licenses/by/4.0/).

\section{Introduction}

In the past year, utilization of sago processing wastes such as pulp and sago water for various applications has been reported as in the manufacture of nanocomposite materials [1], biohydrogen [2-4], fluorescent material [5-8], enzyme-substrate [9], and bioethanol [10,11]. In addition to the high lignocellulose content, the presence of increasing residues is the main cause of the utilization of the results of the sago processing waste [8-10]. Sago water waste has been reported to cause pollution to the aquatic environment [12]. The value of the biological oxygen demand (BOD) and chemical oxygen demand (COD) contained in them affects water quality, where the values for both are $3.4 \mathrm{~g} / \mathrm{L}$ and $11.4 \mathrm{~g} / \mathrm{L}$, respectively [4].

The composition analysis results showed that the sago pulp before pretreatment contained lignocellulose with different percentages. Thangavelu et al. [10] reported lignocellulose sago pulp content consisting of cellulose, hemicellulose, and lignin in 16\%, $9.8 \%$, and 5.2\%, respectively. Whereas [13] reported sago pulp cellulose content, 
hemicellulose, and lignin respectively at $23 \%, 9.2 \%$, and $3.9 \%$. Where every $10 \mathrm{~g}$ of dried sago pulp is estimated to produce bioethanol of $3.85 \mathrm{~g}$, bioethanol focuses on interesting studies as renewable energy in overcoming the world fuel crisis with economical and environmentally friendly advantages [14,15]. Bioethanol can be produced from various sources such as agricultural products and solid waste [12-15]. The manufacturing consists of several stages, including the pretreatment, hydrolysis, fermentation, and recovery stages. Compared to other stages, pretreatment is reported to be an important stage, especially in the production of secondgeneration bioethanol [16-19]. This stage will increase hydrolysis efficiency through the breakdown of the lignocellulose complex structure, which has implications for reducing lignin and hemicellulose content [20-22]. In addition, this stage will break down the cellulose crystal structure into glucose [23-25].

Several pretreatment methods have been used for the release of lignocellulose compounds contained in sago pulp waste, such as microwave hydrothermal [10], enzymes [26,27], acid-enzyme combinations [15,28,29], ion liquids [30-32], and dilute acid solutions [33]. Nevertheless, the pretreatment stage in second-generation bioethanol production is still faced with several problems such as high operational costs and high energy requirements during initial biomass treatment. The release of lignocellulose using alkaline and acid solutions is a pretreatment process that has been commonly used and has several advantages such as high lignin solubility, rapid reaction rates, and increased cellulose accessibility.

In addition to the essence as reported by [15], sago pulp waste can also be in the form of fiber (Figure 1A) whose abundance has not been utilized optimally. Based on these problems, this study reports the optimization of the SPFW bioprocessing based on chloride solution. Based on reports from previous studies, the use of alkaline solutions such as ammonium hydroxide before pretreatment effectively releases lignin from lignocellulosic materials. Meanwhile, chloride solutions such as hydrochloric acid can produce large amounts of sugar $[34,35]$. However, the use of high concentrations causes a high corrosion rate. So that in this study, optimization of the use of chloride solution was carried out during the bioprocessing. Both ammonium hydroxide and hydrochloric acid are expected to be effective in increasing the purity of sago waste cellulose.

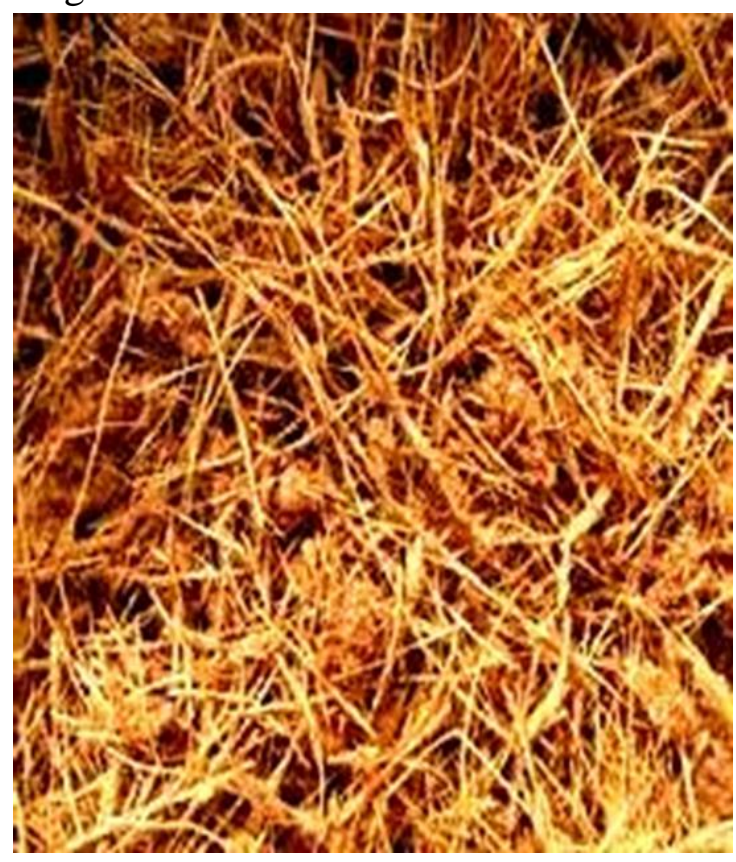

Figure 1. SPFW biomaterial. 


\section{Materials and Methods}

\subsection{SPFW biomaterial preparation.}

SPFW, which still contains starch, is treated through immersion at a temperature of $110^{\circ} \mathrm{C}$ for several hours. Immersion results are then mashed and filtered using a sieve with a pore size of $149 \mu \mathrm{m}$. The fine powder obtained is dried in an oven at $80^{\circ} \mathrm{C}$ until constant weight.

\subsection{Bioprocessing of $S P F W$.}

A total of $25.0 \mathrm{~g}$ of sample was immersed in a 15\%(v/v) ammonium hydroxide solution 24 hours. The immersed solids are separated using a vacuum pump and placed in a volumetric container containing $5 \%(\mathrm{v} / \mathrm{v}) \mathrm{H}_{2} \mathrm{O}_{2}$ solution. Furthermore, it is heated at $65^{\circ} \mathrm{C}$ by giving ultrasonic waves for 1 hour. The residue was washed with distilled water and dried at $70^{\circ} \mathrm{C}$ to a constant weight. Next on, $2.50 \mathrm{~g}$ solids were hydrolyzed using $100.0 \mathrm{~mL}$ hydrochloric acid solution with variations in hydrolysis temperature $75-100^{\circ} \mathrm{C}$, hydrochloric acid concentration $1.5-10 \%$, and hydrolysis time 1-7 hours.

\subsection{Glucose content analysis.}

Samples that were being hydrolyzed were taken $1 \mathrm{ml}$ every 12 hours and put in a microtube, then centrifuged for 10 minutes at a speed of $10,000 \mathrm{rpm}$ to separate the precipitate. After centrifugation, $0.2 \mathrm{ml}$ of solution was taken, and $1.8 \mathrm{ml}$ of distilled water was added to the test tube. Then add $3 \mathrm{ml}$ of DNS solution and vortex it to mix it evenly. Furthermore, heated with boiling water for 10 minutes and cooled with ice water for 10 minutes. Then, after the normal solution's temperature $\left( \pm 25^{\circ} \mathrm{C}\right)$, the absorbance is measured using a spectrophotometer at a wavelength of $540 \mathrm{~nm}$.

\subsection{Cellulose, hemicellulose, and lignin analysis.}

A total of 1.0 grams of SPFW (weight a) to be analyzed for cellulose, hemicellulose, and lignin content is put into a $250 \mathrm{ml}$ round bottom flask, then $150 \mathrm{ml}$ of $\mathrm{H}_{2} \mathrm{O}$ is added to the flask. The reflux mixture at a temperature of $100^{\circ} \mathrm{C}$ with a water bath for 1 hour, then the results are filtered with filter paper. The residue obtained is washed with $300 \mathrm{~mL}$ of hot water to remove the remaining extract that is not wasted. The solid obtained is dried in an oven at $60^{\circ} \mathrm{C}$ until its weight is constant. The weight of this solid is called (weight $b$ ). Next, solid b was put back into the $250 \mathrm{~mL}$ round bottom flask, then $150 \mathrm{~mL}$ of $1 \mathrm{~N} \mathrm{H}_{2} \mathrm{SO}_{4}$ was added and refluxed with a water bath for 1 hour at $100^{\circ} \mathrm{C}$. The result is filtered and washed until the $\mathrm{pH}$ is neutral and the residue is dried to a constant weight in an oven at $60^{\circ} \mathrm{C}$. The weight of this solid is called (weight c). In the next stage, solid c was put back into the $250 \mathrm{~mL}$ round bottom flask, then added $10 \mathrm{~mL}$ of $72 \% \mathrm{H}_{2} \mathrm{SO}_{4}$ and left at room temperature for 4 hours, then added $150 \mathrm{~mL}$ of $\mathrm{H}_{2} \mathrm{SO}_{4} 1 \mathrm{~N}$ and refluxed with a water bath for 1 hour at $100^{\circ} \mathrm{C}$. The result is filtered and washed until the $\mathrm{pH}$ is neutral and the residue is dried to a constant weight in an oven at $60^{\circ} \mathrm{C}$. The weight of this solid is called (weight $d$ ). Then the solid $d$ is ignored and weighed; the weight of this solid is called (weight e). How to find out the levels of cellulose, hemicellulose, and lignin using this method is by using the following equation:

$$
\text { Cellulose content }=\left[\frac{\mathrm{c}-\mathrm{d}}{\mathrm{a}}\right] \times 100 \%
$$




$$
\begin{gathered}
\text { Hemicellulose content }=\left[\frac{\mathrm{b}-\mathrm{c}}{\mathrm{a}}\right] \times 100 \% \\
\text { Lignin content }=\left[\frac{\mathrm{d}-\mathrm{e}}{\mathrm{a}}\right] \times 100 \%
\end{gathered}
$$

\section{Results and Discussion}

\subsection{FTIR, SEM, and XRD analysis.}

Figure 2 shows the FTIR analysis of SPFW before the bioprocessing (dot line) and after the solid line (solid line). Significant differences are seen in absorption intensities and specific wavenumbers. Before bioprocessing, the intensity of IR absorption was relatively weak. This was influenced by the presence of lignin, hemicellulose, and other chemical compounds. Whereas after the bioprocessing, the IR absorption intensity was stronger and sharper. Specific differences for wavenumber values are indicated by the appearance of absorption peaks at $1734.3 \mathrm{~cm}^{-1}$ and $1251.1 \mathrm{~cm}^{-1}$ from SPFW before bioprocessing and absorption at $1429.4 \mathrm{~cm}^{-1}$, $1322.4 \mathrm{~cm}^{-1}, 1157.3 \mathrm{~cm}^{-1}, 1110 \mathrm{~cm}^{-1}$, and $897 \mathrm{~cm}^{-1}$ of SPFW after bioprocessing. Wave numbers $1734.3 \mathrm{~cm}^{-1}$ and $1251.1 \mathrm{~cm}^{-1}$ are specific wavenumbers for lignin-derived from group $\mathrm{C}=\mathrm{O}$ stretching for ketone, carboxyl, and unconjugated esters. Whereas wave number 1429.4 $\mathrm{cm}^{-1}, 1322.4 \mathrm{~cm}^{-1}, 1157.3 \mathrm{~cm}^{-1}, 1110 \mathrm{~cm}^{-1}$, and $897 \mathrm{~cm}^{-1}$ are specific for cellulose. The existence of these wavenumbers reinforces the assumption that the bioprocessing carried out successfully obtains cellulose. The details of specific IR absorption from cellulose can be seen in Table 1.

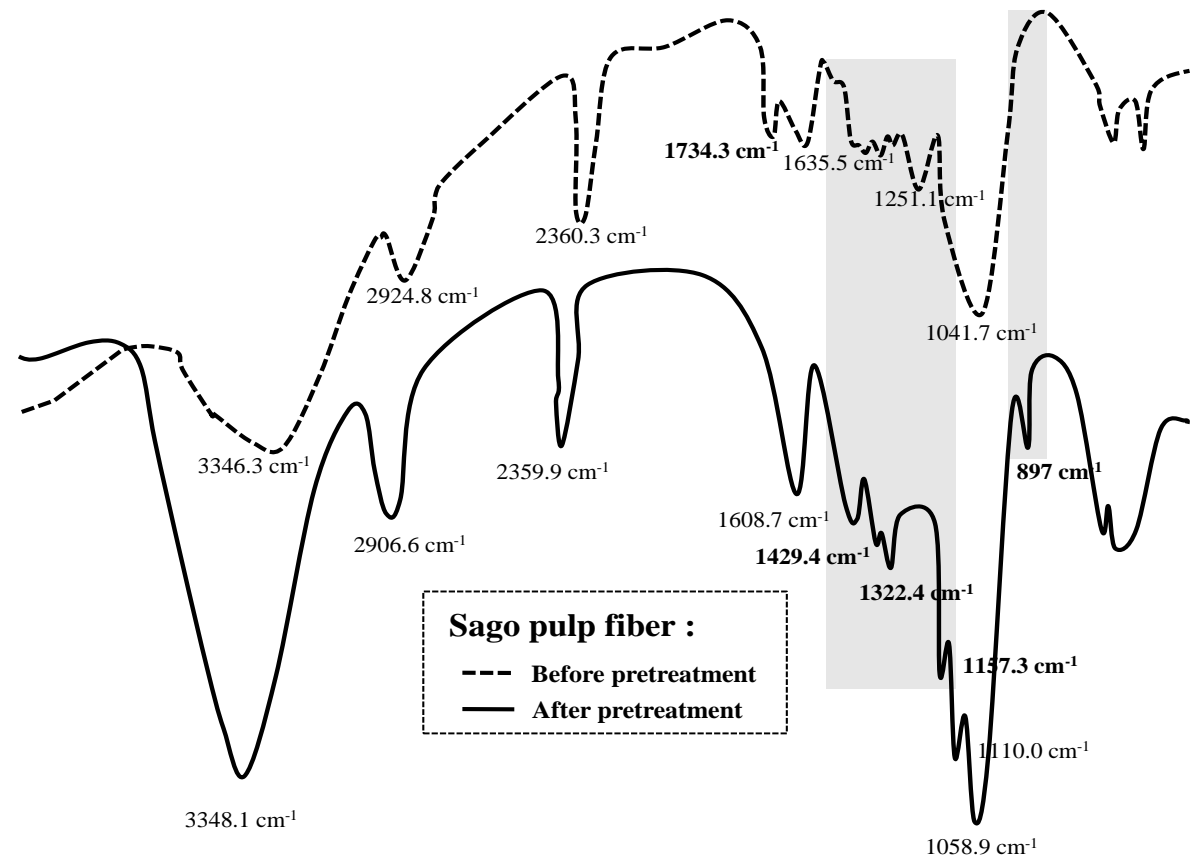

Figure 2. FTIR Analysis of SPFW.

\begin{tabular}{|c|c|}
\hline $\begin{array}{l}\text { Wave numbers } \\
\left(\mathrm{cm}^{-1}\right)\end{array}$ & Explanation \\
\hline 1429.4 & $\mathrm{CH}$ bending* \\
\hline 1322.4 & $\mathrm{CH}_{2}$ bending* \\
\hline 1157.3 & $\mathrm{C}-\mathrm{O}-\mathrm{C}$ asymmetric vibration \\
\hline 1110 & OH bending* \\
\hline 897 & $\begin{array}{l}\text { Shows the typical structure of cellulose } \\
\text { (because of the cellulose glucose ring } \beta \text {-glycosidic bond) }\end{array}$ \\
\hline
\end{tabular}

Table 1. Details of specific IR uptake of sago pulp fiber cellulose. 
Based on SEM analysis results (Figure 3A), the cellulose obtained has a porous, rough, and fibrous surface with irregular length and irregular fiber location. Chemical treatment is reported to affect morphology $[1,38]$. In addition, another cause underlying this problem is the presence of non-cellulose components [39-41]. XRD analysis shows that cellulose has a singlephase (Figure 3B). This is confirmed by the ICDD 9004-34-6 data standards. In addition, the results of the analysis showed that there were 5 crystalline fields of cellulose, namely (101), (10-1), (021), (002), and (040). The degree of crystallinity and crystal size of cellulose were 0.894 and $15 \mathrm{~nm}$, respectively.
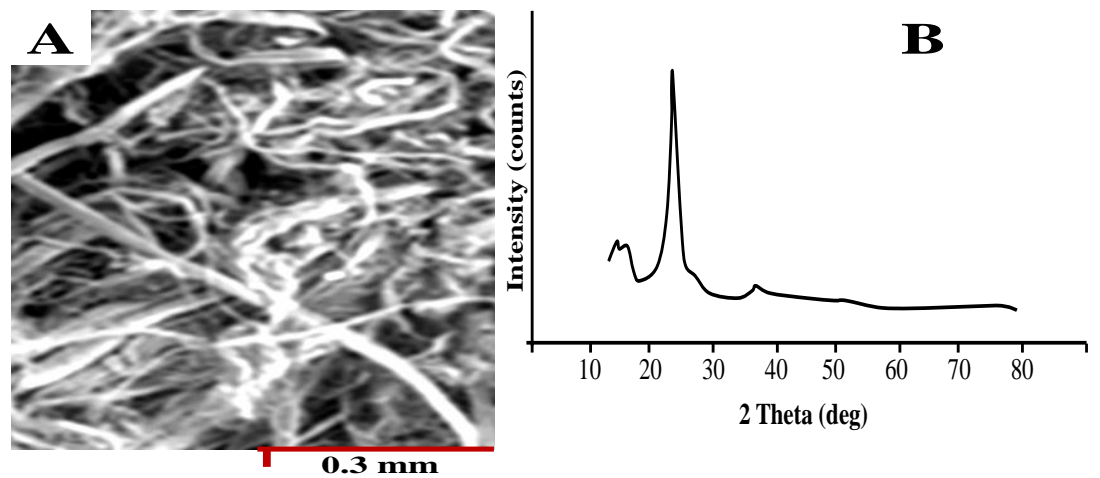

Figure 3. Cellulose of SPFW : (A) SEM analysis and (B) XRD analysis.

\subsection{Optimization of chloride solution.}

The use of ammonium hydroxide before optimization resulted in a reduction in mass and a brown discoloration of the SPFW powder. Ammonium hydroxide causes an increase in the lignocellulose pore size. Besides, it also facilitates the formation of oxidative agents that play an important role in bioprocessing. Oxygen in the ammonium hydroxide solution will be reduced to superoxide radicals $\left(-\mathrm{O}_{2} \bullet\right)$ by reaction with the phenolic hydroxyl group $[42,43]$.
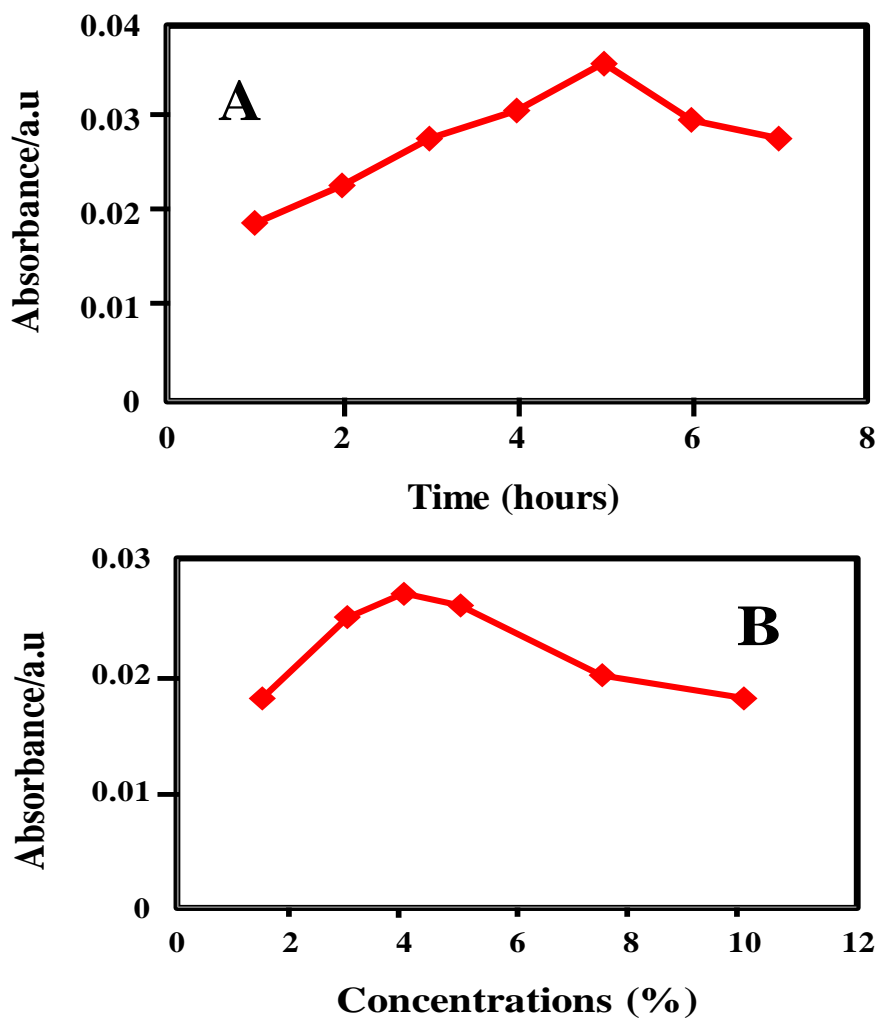


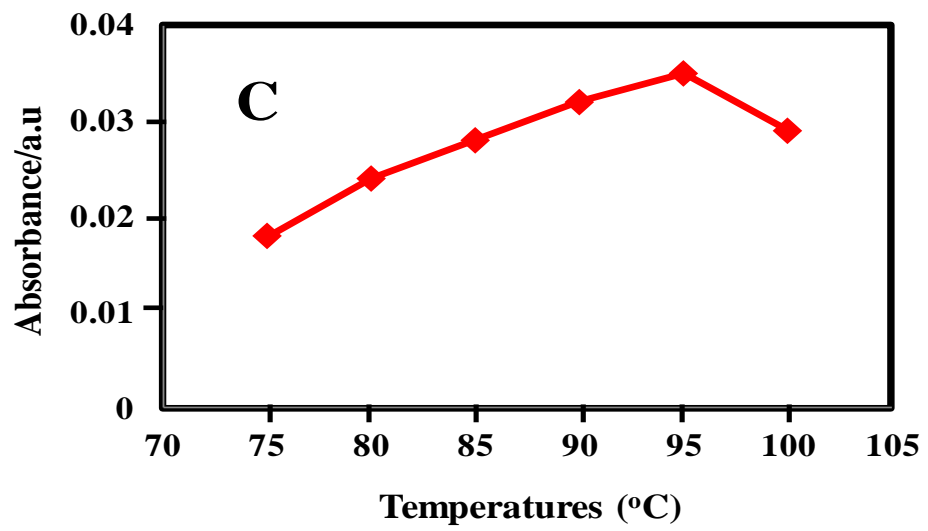

Figure 3. Optimization of sago pulp fiber hydrolysis process: (A) optimization of hydrolysis time; (B) optimization of $\mathrm{HCl}$ concentration; $(\mathbf{C})$ temperature optimization.

Figure 3 shows the optimization results of the chloride solution in the bioprocessing. The optimum value of each treatment is determined based on the amount of dissolved glucose removed. During the bioprocessing, hydrochloric acid will damage the hemicellulose longchain bonds [44-46]. The best optimization results took place at $95 \mathrm{oC}$ using $4 \%$ hydrochloric acid and 5 hours hydrolysis time based on the image.

\subsection{Lignocellulosic content of SPFW.}

The lignocellulose content of the bioprocessing SPFW was then compared with the lignocellulose content of the SPFW without bioprocessing. Figure 4 shows that the SPFW without bioprocessing is dominated by holocellulose compounds such as cellulose and hemicellulose with a percentage of $24.35 \%$ and $27.28 \%$, respectively. Compared with waste sago pith, the holocellulose content of SPFW in simple treatment was much higher. The high holocellulose content makes SPFW without pretreatment potential to be applied as an alternative raw material in producing renewable bioenergy such as bioethanol or biohydrogen.

The chloride solution optimization process was quite effective in increasing cellulose's purity from the SPFW biomaterial. The use of chloride solutions will cause the hemicellulose structure to break down into D-glucose monomers.

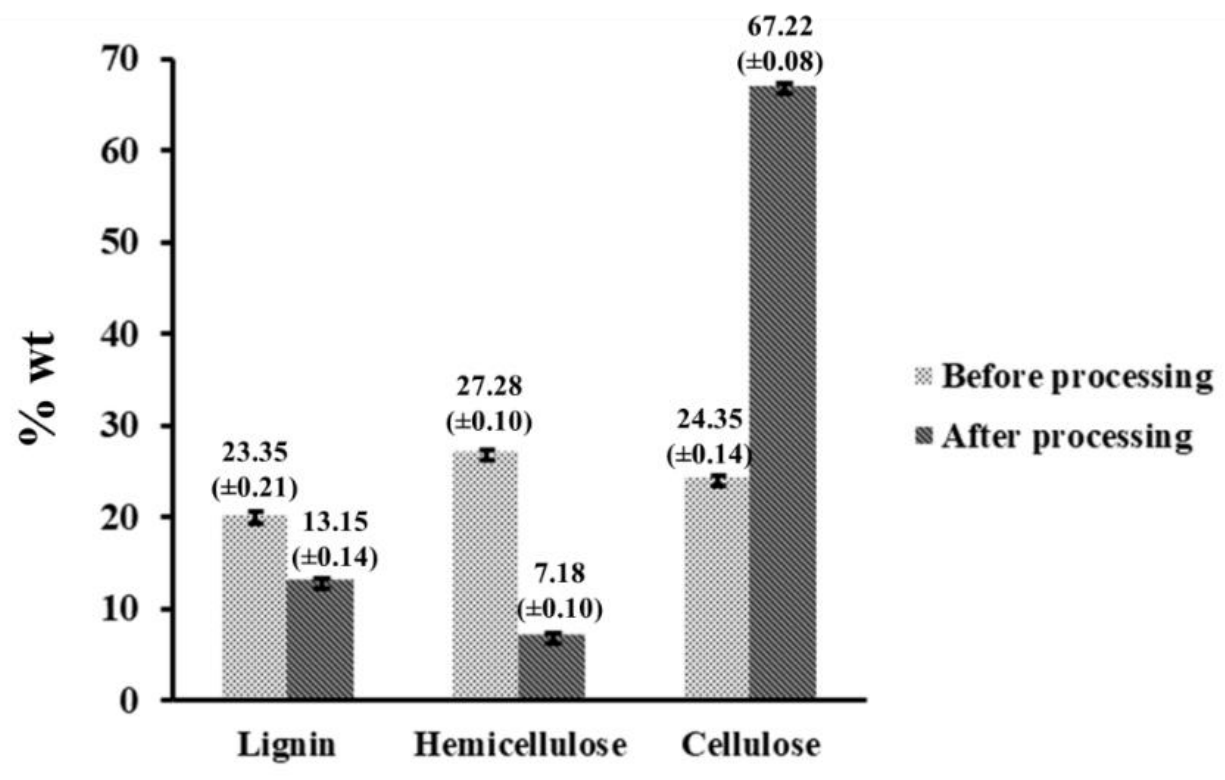

Figure 4. Effectiveness of SPFW bioprocessing. 
Meanwhile, the use of ammonium hydroxide before the hydrolysis process will specifically reduce the lignin content. In general, the effectiveness of the bioprocessing is shown in Figure 4. The image shows a decrease in the content of lignin and hemicellulose after bioprocessing. The SPFW delignification process's efficiency uses an ammonium hydroxide solution of $35 \%$, while the hydrolysis process uses hydrochloric acid by $74 \%$. The purity of SPWF cellulose after bioprocessing increased dramatically with the level of purity obtained by $67.22 \%$.

\section{Conclusions}

The utilizing of chloride solution in the SPFW biomaterial pretreatment process succeeded in increasing the purity of cellulose. The optimization process is the initial stage for developing the hydrolysis method based on chloride solution. So that SPFW cellulose purification can be more effective, the hydrolysis residue obtained can be used at the fermentation stage. The cellulose purity obtained was $67 \%$, with the characteristic presence of IR absorption at wave number $897 \mathrm{~cm}^{-1}$.

\section{Funding}

This research was conducted through independent funding from the author.

\section{Acknowledgments}

This research has no acknowledgment.

\section{Conflicts of Interest}

The authors declare that this article has no conflict of interest.

\section{References}

1. de Souza, A. G.; Rocha, D. B.; Kano, F. S.; dos Santos Rosa, D. Valorization of industrial paper waste by isolating cellulose nanostructures with different pretreatment methods. Resources, Conservation and Recycling 2019, 143, 133-142, https://doi.org/10.1016/j.resconrec.2018.12.031.

2. Ulhiza, T. A.; Puad, N. I. M.; Azmi, A. S. Optimization of culture conditions for biohydrogen production from sago wastewater by Enterobacter aerogenes using Response Surface Methodology. International Journal of Hydrogen Energy 2018, 43, 22148-22158, https://doi.org/10.1016/j.ijhydene.2018.10.057.

3. Yunus, N.; Jahim, J. M.; Anuar, N.; Abdullah, S. R. S.; Kofli, N. T. Batch fermentative hydrogen production utilising sago (Metroxylon sp.) starch processing effluent by enriched sago sludge consortia. International Journal of Hydrogen Energy 2014, 39, 19937-19946, https://doi.org/10.1016/j.ijhydene.2014.10.015.

4. Hasyim, R.; Imai, T.; Sompong, O.; Sulistyowati, L. Biohydrogen production from sago starch in wastewater using an enriched thermophilic mixed culture from hot spring. International journal of hydrogen energy 2011, 36, 14162-14171, https://doi.org/10.1016/j.ijhydene.2011.04.211.

5. Amin, N.; Sabli, N.; Izhar, S.; Yoshida, H. Sago Wastes and Its Applications. Pertanika J. Sci. \& Technol 2019, 27, 1841-1862.

6. Fan, H.; Zhang, M.; Bhandari, B.; Yang, C. Food waste as a carbon source in carbon quantum dots technology and their applications in food safety detection. Trends in Food Science \& Technology 2020, 95, 86-96. https://doi.org/10.1016/j.tifs.2019.11.008.

7. Allo, Y. K.; Togibasa, O. Synthesis and Characterization of Activated Carbon from Sago Waste (Metroxylon sagu) with $\mathrm{ZnCl}_{2}$ Activation and $\mathrm{HNO}_{3}$ Modification. Journal of the Indonesian Chemical Society 2019, 2 , 48. https://doi.org/10.34311/jics.2019.02.1.48.

8. Kang, C.; Huang, Y.; Yang, H.; Yan, X. F.; Chen, Z. P. A review of carbon dots produced from biomass wastes. Nanomaterials 2020, 10, 2316. https://doi.org/10.3390/nano10112316. 
9. Lalaoui, N.; David, R.; Jamet, H.; Holzinger, M.; Le Goff, A.; Cosnier, S. Hosting adamantane in the substrate pocket of laccase: direct bioelectrocatalytic reduction of $\mathrm{O}_{2}$ on functionalized carbon nanotubes. Acs Catalysis 2016, 6, 4259-4264. https://doi.org/10.1021/acscatal.6b00797.

10. Thangavelu, S. K.; Rajkumar, T.; Pandi, D. K.; Ahmed, A. S.; Ani, F. N. Microwave assisted acid hydrolysis for bioethanol fuel production from sago pith waste. Waste management 2019, 86, 80-86. https://doi.org/10.1016/j.wasman.2019.01.035.

11. Rijal, M. Bioethanol from Sago Waste Fermented by Baker's and Tapai Yeast as a Renewable Energy Source. bioRxiv 2020, https://doi.org/10.1101/2020.01.03.894691.

12. Bukhari, N. A.; Loh, S. K.; Bakar, N. A.; Ismail, M. Hydrolysis of residual starch from sago pith residue and its fermentation to bioethanol. Sains Malaysiana 2017, 46, 1269-1278. https://doi.org/10.17576/jsm-20174608-12.

13. Linggang, S.; Phang, L. Y.; Wasoh, M. H.; Abd-Aziz, S. Sago pith residue as an alternative cheap substrate for fermentable sugars production. Applied biochemistry and biotechnology 2012, 167, 122-131. https://doi.org/10.1007/s12010-012-9592-0.

14. Thangavelu, S. K.; Ahmed, A. S.; Ani, F. N. Review on bioethanol as alternative fuel for spark ignition engines. Renewable and Sustainable Energy Reviews 2016, 56, 820-835. https://doi.org/10.1016/j.rser.2015.11.089.

15. Awg-Adeni, D. S.; Bujang, K. B.; Hassan, M. A.; Abd-Aziz, S. Recovery of glucose from residual starch of sago hampas for bioethanol production. BioMed research international 2013. https://doi.org/10.1155/2013/935852.

16. Zhu, F. Recent advances in modifications and applications of sago starch. Food Hydrocolloids 2019, 96, 412423. https://doi.org/10.1016/j.foodhyd.2019.05.035.

17. Hassimi, A. H.; Hafiz, R. E.; Muhamad, M. H.; Abdullah, S. R. S. Bioflocculant production using palm oil mill and sago mill effluent as a fermentation feedstock: Characterization and mechanism of flocculation. Journal of environmental management 2020, 260, 110046. https://doi.org/10.1016/j.jenvman.2019.110046.

18. Luque, L.; Oudenhoven, S.; Westerhof, R.; van Rossum, G.; Berruti, F.; Kersten, S.; Rehmann, L. Comparison of ethanol production from corn cobs and switchgrass following a pyrolysis-based biorefinery approach. Biotechnology for biofuels 2016, 9, 242. https://doi.org/10.1186/s13068-016-0661-4.

19. Zabed, H.; Faruq, G.; Sahu, J. N.; Azirun, M. S.; Hashim, R.; Nasrulhaq Boyce, A. Bioethanol production from fermentable sugar juice. The Scientific World Journal 2014. https://doi.org/10.1155/2014/957102.

20. Oyeleke, S. B.; Dauda, B. E. N.; Oyewole, O. A.; Okoliegbe, I. N.; Ojebode, T. Production of bioethanol from cassava and sweet potato peels. Advances in Environmental Biology 2012, 241-246.

21. Aditiya, H. B.; Mahlia, T. M. I.; Chong, W. T.; Nur, H.; Sebayang, A. H. Second generation bioethanol production: A critical review. Renewable and sustainable energy reviews 2016, 66, 631-653. https://doi.org/10.1016/j.rser.2016.07.015.

22. Mood, S. H.; Golfeshan, A. H.; Tabatabaei, M.; Jouzani, G. S.; Najafi, G. H.; Gholami, M.; Ardjmand, M. Lignocellulosic biomass to bioethanol, a comprehensive review with a focus on pretreatment. Renewable and Sustainable Energy Reviews 2013, 27, 77-93. https://doi.org/10.1016/j.rser.2013.06.033.

23. Sari, A. A.; Kurniawan, H. H.; Nurdin, M.; Abimanyu, H. Decolorization of black liquor wastewater generated from bioethanol process by using oil palm empty fruit bunches. Energy Procedia 2015, 68, 254262. https://doi.org/10.1016/j.egypro.2015.03.254.

24. Triwahyuni, E.; Hariyanti, S.; Dahnum, D.; Nurdin, M.; Abimanyu, H. Optimization of saccharification and fermentation process in bioethanol production from oil palm fronds. procedia Chemistry 2015, 16, 141-148. https://doi.org/10.1016/j.proche.2015.12.002.

25. Maulidiyah, M.; Natsir, M.; Fitrianingsih, F.; Arham, Z.; Wibowo, D.; Nurdin, M. Lignin Degradation of Oil Palm Empty Fruit Bunches using $\mathrm{TiO}_{2}$ Photocatalyst as Antifungal of Fusarium Oxysporum. Oriental Journal of Chemistry 2017, 33(6), 3101-3106. https://doi.org/10.13005/ojc/330651.

26. Harihastuti, N.; Rame, R.; Djayanti, S. High Performance of Enzymatic Bioprocess for Production of Biomassed-based Bioethanol of Sago Palm Fiber Waste. Jurnal Riset Teknologi Pencegahan Pencemaran Industri 2018, 9, 37-45. http://dx.doi.org/10.21771/jrtppi.2018.v9.no2.p37-45.

27. Hammado, N.; Utomo, S.; Budiyono, B. Characteristic lignocellulose of sago solid waste for biogas production. Journal of Applied Engineering Science 2020, 18, 157-164. https://doi.org/10.5937/jaes1824711.

28. Suresh, T.; Sivarajasekar, N.; Balasubramani, K.; Ahamad, T.; Alam, M.; Naushad, M. Process intensification and comparison of bioethanol production from food industry waste (potatoes) by ultrasonic assisted acid 
hydrolysis and enzymatic hydrolysis: Statistical modelling and optimization. Biomass and Bioenergy 2020, 142, 105752. https://doi.org/10.1016/j.biombioe.2020.105752.

29. Bankar, S. B.; Nimbalkar, P. R.; Khedkar, M. A.; Chavan, P. V. Biobutanol: Research Breakthrough for its Commercial Interest. Liquid Biofuel Production 237-283. https://doi.org/10.1002/9781119459866.ch8.

30. Lee, K. M.; Ngoh, G.-C.; Chua, A. S. M.; Yoon, L. W.; Nam, T.; Lee, M. G. Comparison study of different ionic liquid pretreatments in maximizing total reducing sugars recovery. BioResources 2014, 9, 1552-1564.

31. Abushammala, H.; Mao, J. A review on the partial and complete dissolution and fractionation of wood and lignocelluloses using imidazolium ionic liquids. Polymers 2020, $12, \quad 195$. http://doi.org/10.3390/polym12010195.

32. Chemmangattuvalappil, N. G.; Ng, D. K. S.; Ng, L. Y.; Ooi, J.; Chong, J. W.; Eden, M. R. A Review of Process Systems Engineering (PSE) Tools for the Design of Ionic Liquids and Integrated Biorefineries. Processes 2020, 8, 1678. https://doi.org/10.3390/pr8121678.

33. Yemiş, O.; Mazza, G. Acid-catalyzed conversion of xylose, xylan and straw into furfural by microwaveassisted reaction. Bioresource technology 2011, 102, https://doi.org/10.1016/j.biortech.2011.04.050.

34. Nguyen, T.-A. D.; Kim, K.-R.; Han, S. J.; Cho, H. Y.; Kim, J. W.; Park, S. M.; Sim, S. J. Pretreatment of rice straw with ammonia and ionic liquid for lignocellulose conversion to fermentable sugars. Bioresource Technology 2010, 101, 7432-7438. https://doi.org/10.1016/j.biortech.2010.04.053.

35. Mustafa, H. M.; Hayder, G.; Jagaba, A. H. Microalgae: A Renewable Source for Wastewater Treatment and Feedstock Supply for Biofuel Generation. Biointerface Res. In Appl. Chem 2021, 11, 7431-7444. http://doi.org/10.33263/BRIAC111.74317444.

36. Naduparambath, S.; Jinitha, T. V.; Shaniba, V.; Sreejith, M. P., Balan, A. K.; Purushothaman, E. Isolation and characterisation of cellulose nanocrystals from sago seed shells. Carbohydrate polymers 2018, 180, 1320. https://doi.org/10.1016/j.carbpol.2017.09.088.

37. Mishra, S. P.; Patra, A. R.; Das, S. Methylene blue and malachite green removal from aqueous solution using waste activated carbon. Biointerface Res Appl Chem 2020, 11, 7410-7421. https://doi.org/10.33262/BRIAC111.74107421.

38. Dariva, R.; Colet, R.; Manzoli, A.; Fernandes, I. A.; de Souza Hassemer, G.; Cansian, R. L.; Valduga, E. Structural and Techno-Functional Properties of Cassava Starches and Application on Cheese Bread. Biointerface Res Appl Chem 2020, 11, 7400-7409. https://doi.org/10.33262/BRIAC111.74007409.

39. Chirayil, C. J.; Joy, J.; Mathew, L.; Mozetic, M.; Koetz, J.; Thomas, S. Isolation and characterization of cellulose nanofibrils from Helicteres isora plant. Industrial Crops and Products 2014, 59, $27-34$. https://doi.org/10.1016/j.indcrop.2014.04.020.

40. Lu, Z.; An, X.; Zhang, H.; Lui, L.; Dai, H.; Cao, H.; Lu, Bin.; Liu, H. Cationic cellulose nano-fibers (CCNF) as versatile flocculants of wood pulp for high wet web performance. Carbohydrate Polymers 2020, 229, https://doi.org/10.1016/j.carbpol.2019.115434.

41 Zhang, Q.; Zhang, L.; Wu, W.; Xiao, H. Methods and applications of nanocellulose loaded with inorganic nanomaterials:A review, Carbohydrate Polymer 2020, 229, https://doi.org/10.1016/j.carbpol.2019.115454.

42. Shao, Q.; Chundawat, S. P. S.; Krishnan, C.; Bals, B.; da Costa Sousa, L.; Thelen, K. D., Balan, V. Enzymatic digestibility and ethanol fermentability of AFEX-treated starch-rich lignocellulosics such as corn silage and whole corn plant. Biotechnology for biofuels 2010, 3, 12. https://doi.org/10.1186/1754-6834-3-12.

43. Danielewicz, D.; Slusarska, B. S. Miscanthus $\times$ giganteus stalks as a potential non-wood raw material for the pulp and paper industry. Influence of pulping and beating conditions on the fibre and paper properties. Industrial Crops and Products 2020, 141. https://doi.org/10.1016/j.indcrop.2019.111744.

44. Delbecq, F.; Wang, Y.; Muralidhara, A.; El Ouardi, K.; Marlair, G., \& Len, C. Hydrolysis of hemicellulose and derivatives-A review of recent advances in the production of furfural. Frontiers in chemistry 2018, 6 , 146. https://doi.org/10.3389/fchem.2018.00146.

45. Ávila, P. F.; Fátima, M. M.; Costa, A. de A. Goldbeck, R. Xylooligosaccharides production by commercial enzyme mixture from agricultural wastes and their prebiotic and antioxidant potential. Bioactive Carbohydrates and Dietary Fibre 2020, 24. https://doi.org/10.1016/j.bcdf.2020.100234.

46. Matsakas, L.; Gerber, M.; Yu, L.; Rova, U. Christakopoulus, P. Preparation of low carbon impact lignin nanoparticles with controllable size by using different strategies for particles recovery. Industrial Crops and Products 2021, 147, https://doi.org/10.1016/j.indcrop.2020.112243 